\title{
Threats to Niger-Delta Wetlands: A Case Study of Apoi Creek Forest
}

\section{Iwebuke Edo, Eike Albrecht}

Faculty 5, Business, Law and Social Sciences, Department of Civil Law and Public Law with Reference to the Law of Europe and the Environment, Brandenburg University of Technology Cottbus-Senftenberg (BTU), Germany

Email: merakin4real@yahoo.com

How to cite this paper: Edo, I. and Albrecht, E. (2021) Threats to Niger-Delta Wetlands: A Case Study of Apoi Creek Forest. Open Journal of Ecology, 11, 136-147. https://doi.org/10.4236/oje.2021.112012

Received: September 15, 2020

Accepted: February 7, 2021

Published: February 10, 2021

Copyright $\odot 2021$ by author(s) and Scientific Research Publishing Inc. This work is licensed under the Creative Commons Attribution-NonCommercial International License (CC BY-NC 4.0). http://creativecommons.org/licenses/by-nc/4.0/

\begin{abstract}
Wetlands are essential subsystem of the general ecosystem with so many functions; like purification and sustenance of ground and surface water resources on earth, and its numerous services that it offers to animal, plant, human (local communities) and the nation's economy at large. The issue of wetland degradation and wetland loss started when the world was seeing wetlands as unproductive, unhealthy land full of snakes and crocodiles. Niger Delta wetland ecosystem is a very rich and important ecosystem in Nigeria, it harbours some endemic spices both flora and fauna, a hotspot for biodiversity and it is of high economic value for the local communities. This paper reviews that changes have occurred in the study area and the Niger Delta wetlands. The changes were identified to be as a result of human activities (anthropogenic activities) and the ongoing environmental pressure resulting from the large scale oil exploration and exploitation, pipeline installation, urban expansion and agriculture. These were identified as some of the major threats to Apoi creek forest wetland. These findings were obtained after analysing the data obtained which helped to raise awareness that can assist to effectively monitor, protect and conserve the wetland ecosystem.
\end{abstract}

\section{Keywords}

Wetland, Biodiversity, Niger-Delta, Ecosystem

\section{Introduction}

Apoi creek forest wetlands are being threatened as result of human activities in the area. The study area is one of the two Ramsar sites in the Niger Delta region and one of the eleven Ramsar sites in Nigeria. Wetlands according to article 1 of the Ramsar convention defined wetland as "areas of marsh, fen, peat-land or 
water, whether natural or artificial, permanent or temporary, with water that is static or flowing, fresh, brackish or salt, including areas of marine water, the depth of which at low tide does exceed $6 \mathrm{~m}$ " [1]. Wetlands are known to be terrestrial or semi-terrestrial ecosystems which are considered to have low quality drainage, slow waters or unfrequently standing water body that is usually filled with soil. Furthermore, wetland is therefore characterized as bog, marsh or swamp in accordance with the plant habitat and related soil components. These are also recognized and termed as boundary ecosystem as a result of their occurrence in nature at water body boundaries or line [2]. Wetlands are very important due to their ecological functions including water retention and purification, their ability or capability to control flood and erosion. Wetlands are known to be useful for their treatment and recycling of wastewater functions and also serve as breeding and rearing place for animals and aquaculture resources. Wetlands are also used for recreational activities like; bird watching or sailing, and also for nutrient decomposition or fetidness and recycling. With these abundant values that are being derived from wetlands, anthropogenic activities are having much pressure on the wetlands resulting in wetland loss. Human induced impacts have made some of the wetlands and some of its species gone into extinction [3]. According to the study carried out by [4], talking about climate change and its impact on wetlands functions, it shows that wetlands are known to be one of the utmost ecosystems that is at risk as a result of anthropogenic activities that is being intensified by climate change. However, [4] acknowledged that this change in climate has the possibility of altering the feature of wetlands like runoff rate, flow, temperature and general physical characteristics of the ecosystems. Such disturbance and alteration will therefore have effects on the functions of wetlands and thereby affects the goods and services it provides that humans depend on.

Generally, wetlands occupy about 12.8 million $/ \mathrm{km}^{2}$ on the earth surface [4]. However, a total of about $1,342,162.53 \mathrm{~km}^{2}$ are internationally recognised as Ramsar sites which include the marine and coastal areas. Currently, about half $(50 \%)$ of the wetlands have been lost as a result of drainage, and water diversion and specifically on its impact in respect to the population of hunted waterfowl. This has shown up consistently and it has raised interest since the 1920s in North America [5] [6] and in Europe in the early 1960s [7]. In Nigeria there are many important wetland belts, these belts are located in Niger, Benue and Chad Basins. Presently, Nigerian wetlands cover a total area of about $923,768 \mathrm{~km}^{2}$ which represent $2.6 \%$ of the country's total area. The Niger Delta wetland is the most talked about wetland in Nigeria, as a result of its rate of degradation and decreasing nature, and it is the most important wetland in Nigeria due to its richness (biodiversity), largest in continent and third largest in the world [8]. In the 1960s, the reason to protect wetland arose due to the fast deterioration, however in the year 1971 the governmental and non-governmental organizations that have interest in biodiversity and wetland resources came up with an international convention called Ramsar. The idea for establishing Ramsar Con- 
vention is to find the best approach to protect and use its resources in a sustainable manner. It was adopted in the year 1971 and entered into force in 1975. Also, the objective is to conserve and designate wetland as a Ramsar site of international importance in meeting the requirements [9].

\subsection{Problem Statement}

Population growth has negative impacts on wetlands resulting to wetlands degradation in all levels (regional, national and globally), for the fact that population keep increasing, there will be more pressure on wetlands and its resources at all levels.

\subsection{Niger-Delta and Apoi Creek Forest}

Niger Delta is geographically located in Southern part of Nigeria, covering an area of about $70,000 \mathrm{~km}^{2}$, it consists of nine states which are as follows: Abia, Akwa-Ibom, Bayelsa, Cross River, Delta, Edo, Imo, Ondo and Rivers States as shown in Figure 1. In terms of culture, the Niger Delta is culturally diverse with numerous language and ethnics groups [10]. The Niger Delta ecosystem is classified into four main zones, from an environmental point of view (with varying boundaries determined by the seasonal flooding patterns) as listed: mangrove swamps, freshwater swamps, saltwater rainforest, and sandy beach ridges, and it is bounded to the South by the Atlantic [11].

Apoi Creek Forest is located in Bayelsa State with a total area of $292.13 \mathrm{~km}^{2}$. Apoi Creek Forest is classified as a lowland swamp-forest, which is located in the Centre of Niger Delta and this forest is constituted by marshes, mangrove and fresh water swamps, it is dense and rich with numerous ecologically and
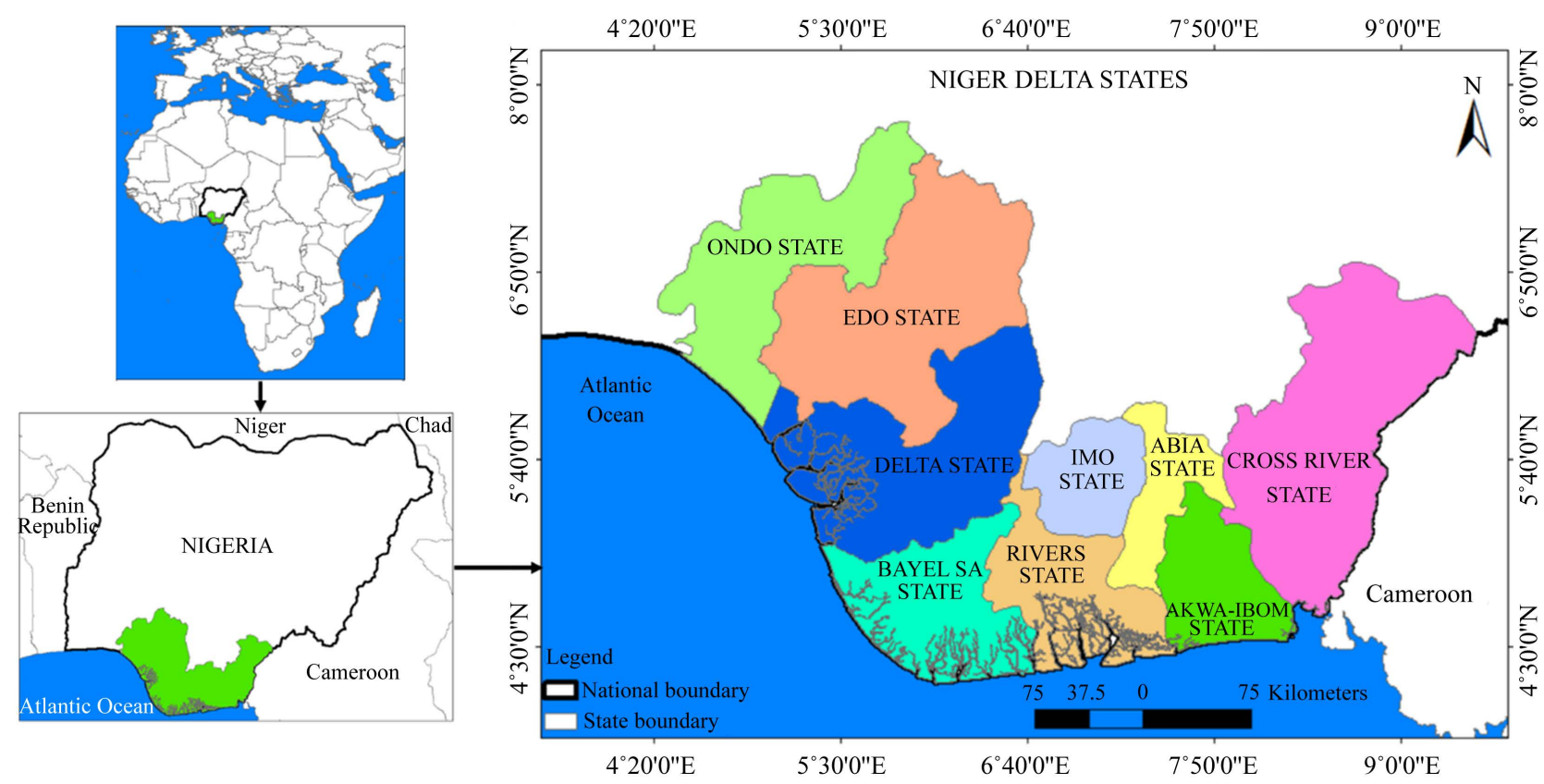

Figure 1. Map of Niger Delta showing its states. Source: Author. 
economically valuable flora and fauna species. Apoi creek forest harbours some endemic and endangered species like the Niger Delta Red Colobus monkey amongst other species, and it serves as a vital spawning and nursery ground for aquatic animals like fish [8]. Figure 1 is a map of Africa showing the location of Nigeria, map of Nigeria showing the location Niger Delta and map of Niger Delta showing the states and boundaries.

The Apoi Creek Forest has impacted or contributed to the livelihood of local residents by providing or utilizing non-timber forest products, fisheries and agricultural land. Digging of canals for the purpose of transportation of timbers is activities that threaten this wetland. This site is technically said to be owned by the state, but virtually overseen by customary authority of local families and communities. The Niger Delta Wetlands Centre works for the study and protection of the Red Colobus monkey and its habitat, the Apoi Creek Forest is a Ramsar site with registration number 1751. According to [12], the Niger Delta Red Colobus monkey (Procolobus epieni) is endemic to an area of about 1500 $\mathrm{km}^{2}$ of marsh forest which is the centre of the Niger Delta where the Apoi Creek Forest is located. It has been noticed that the number of the said monkey is decreasing as a result of hunting and habitat degradation. The Niger Delta Red Colobus monkey has been classified by IUCN to be critically endangered and it's currently listed among the 25 world most endangered primates [13]. Figure 2 shows a satellite image of Apoi creek forest area.

The species are being hunted for the purpose of consumption, threat as a result of logging activities and hydrological changes within the marsh forest. Also, as a result of construction activities from the large canals in the region by the oil and gas companies. In addition, dredging of smaller canals for the purpose of transporting the logged timbers poses threat to this species of monkeys. Apoi Creek Forest Reserve is said to have been misused or neglected by the Bayelsa State Department of Forestry which is under-funded by the state government and lacks the resources to protect it effectively [15]. Presently, the site is being managed by several communities that surround the site: Apoi, Gbanraun, Kokologbene, Lobia and Okubie. The biodiversity value of this site is recognized universally due to the IUCN recognition for its endemic species like the Niger

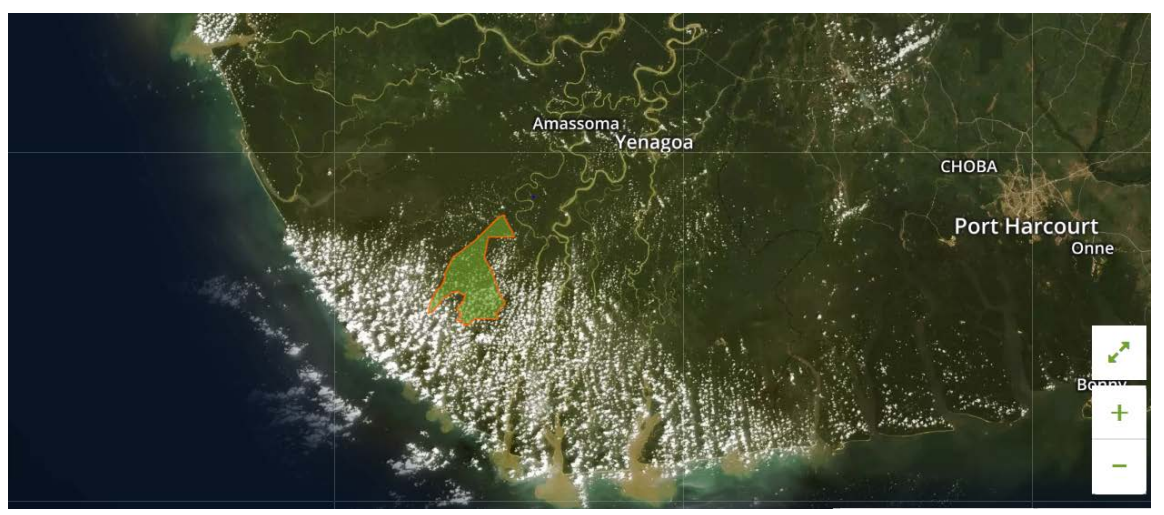

Figure 2. Satellite image of Apoi Creek forest. Source: [14]. 
Delta Red Colobus. The marsh forest habitat is shared with two other threatened primates: The Nigerian White Throated Guenon (Cercopithecus erythrogaster pococki) and the red-capped mangabey (Cercocebus torquatus), each listed as vulnerable in the Red List of IUCN [12]. Apoi Creek Forest as a Ramsar site is supposed to be protected by both the federal and state government not just the Bayelsa state government alone. For the purpose of the endemic and endangered species that is found in this site, there is a need for both governments to strengthen the measures and methods of its management. However, this means that there is an urgent need to critically review the available law in Nigeria for management and protection of wetlands. Also, to review the implementation and enforcement process of the available law in other to effectively protect the wetlands and its resources.

According to [12], wetland degradation in Apoi Creek Forest is attributed to the increasing logging for commercial activities, unsustainable way of collecting firewood by local dwellers and degradation of the wetland for the purpose agricultural activities. However, the impact of these activities has been investigated in Bayelsa by [15] and the results have shown that about 3\% of the forest in the area is lost annually (200,000 forest trees per year). This study further explains that the pressure on wetlands is as result of urban sprawl and farmland reclamation, which in turn is as a result of the growing population in the region with $25 \%$ increase between 1980 and 2000 [16]. The average population density in Bayelsa is estimated to be about 450 people per $\mathrm{km}^{2}$ and the highest density which is found in the freshwater swamp zone [15]. The increasing pressure of industrialization and urbanization is a strong evidence in the study area and this has a negative impact on freshwater forests and mangroves within the area. As far as population keeps increasing as projected, this trend will remain so or even increase in the future as ongoing infrastructural development further opens up previously inaccessible regions [8]. According to study carried out by [15], it shows that from the year 1984 till 2000 there has been consistent decrease in the years examined in terms of the mean of Normalized Difference in the Vegetation Index (NDVI). However, it indicates that Apoi Creek Forest is degrading and appropriate measures have to be put in place to monitor and see that its resources are used or exploited in a sustainable manner.

\section{Methodology}

Secondary data was used for this study.

\subsection{The Major Threats Facing Niger-Delta Wetland (Apoi Creek Forest) Dredging}

Dredging is a process of removing the large tiles of seafloor, by either lifting or sucking it out thereby dumping it in a different place, while reclamation areas are a water area or sea area which is turned into land [17]. This action is usually carried out in coastal waters area in other for large ships to gain access to ports. During dredging the seabed, sea grasses and marine animals that do inhabit the 
sea floor are eliminated in the process. Furthermore, dredging of an area brings about loss of a high number of mobile species, for example turtles are drawn or pinched into the pathway of the dredgers during the dredging process. According to [17], dredging is known to results into or bring about physio-chemical changes in water in delta. This is in relation to $\mathrm{pH}$ level, conductivity, dissolved oxygen, oxygen demand, total dissolved and suspended solids (TDS and TSS), turbidity and sulphate. The process of dredging is known to cause water degradation and also affects the aquatic life. Dredging is a very common activity going on in the Niger Delta area to enable ship to belt for transporting crude, timber products and agricultural products in the area.

\subsection{Oil Spill}

Oil spill poses a major threat to fresh water and marine environment. If not checked or well checked, it can result to ecosystems destruction in the area. The Niger Delta wetland is known to be one of the ten richest wetlands and marine ecosystems known in the worldwide [18]. In Nigeria, all oil exploration companies are located in the Niger Delta region, which is the main source of revenue for the country. Oil and gas has contributed so much to the growth and development of the country [10]. The oil production statistics for Nigeria, shows that Nigeria as a country has an estimated 36.2 billion barrels of oil reserve, which makes Nigeria to be the second largest oil reserve in African. The Nigerian oil sector is known to account for over 95 percent of its export earnings and around 85 percent of its revenues. Its input in terms of GDP was said to be 21.9 and 19.4 percent in the year 2006 and 2007 respectively [18]. Owing to the enormous oil and gas reserves in the region, oil activities has been up and running since oil was first discovered in 1950s till date. The negative aspect of this, is the unsustainable manner in which the oil exploration and exploitation activities have rendered or caused the region to be known as one of the most damaged ecosystem in the world [19]. Oil spills in the region have been occurring for several decades now and they have characterised the area by contaminating the rivers, stream and forest in the area. According to [19], in Niger Delta approximately 1.5 million tons of oil have been spilled over a period of some decades, majority of them are not cleaned while few are partially cleaned.

\subsection{Ogoniland and Oil}

In Niger Delta there are so several indigenous groups which include the people of Ogoniland. The people of Ogoniland depend on natural resources for their livelihood. Regardless of the money being generated as revenue from areas like Ogoniland, which was valued to be about $\$ 30$ billion, relatively little or nothing has done for the people [20]. The people of Ogoni are suffering from environmental issues ranging from oil spills, gas flares, and significant environmental pollution which has destroyed or impacted their farmlands, water, and fishing activities known to be the main source of their livelihood. The agencies of the government responsible for oil spill related issues have failed in terms of moni- 
toring the extent of the oil spills in the country. Thereby, enforcing the available environmental laws that is required or needed to quicken oil spill response for oil and gas merchants. However, Nigeria is said to provide unknown or diminutive privileges for indigenous groups in the area, as no clean-up has taken place in Ogoniland [20]. As seen in Figure 3, water body showing oil on the surface, which means that the water is contaminated and not useful to both humans and animals.

The Niger Delta ecosystem supports a wide variety of flora (timber species, vegetables, fruits, nuts and seeds, medicinal plants, palm trees, tannins, and grasses) and fauna (monkeys, apes, otters, squirrels, antelopes, reptiles, 330 different species of birds; insects and invertebrates) species, all these are degrading as a result of oil spillage rapture of oil pipelines [21].

\subsection{Wetland Degradation}

Wetland degradation is known to exist in the form of over-utilization of its resources, clearing of vegetation for agricultural purpose, sand filling of wetlands for the purpose of construction and installation for industrial facilities, etc. All these bring changes to the natural state of wetlands by impacting the fauna and flora of the wetland system. According to [2] wetland loss can be defined as the loss of wetland areas due to the conversion of the areas to a mainland for the purpose of agriculture, development (urban expansion) etc. Wetland loss could also be referred to as modification of vegetated wetland to upland areas or to inundated environment that originally sustained organism that are dependent of wetlands. Wetland degradation is said to be the deficiency of wetland due to human activities. However, wetlands are considered to be lost if they have been degraded to the level that they have no substantial natural values and functions.

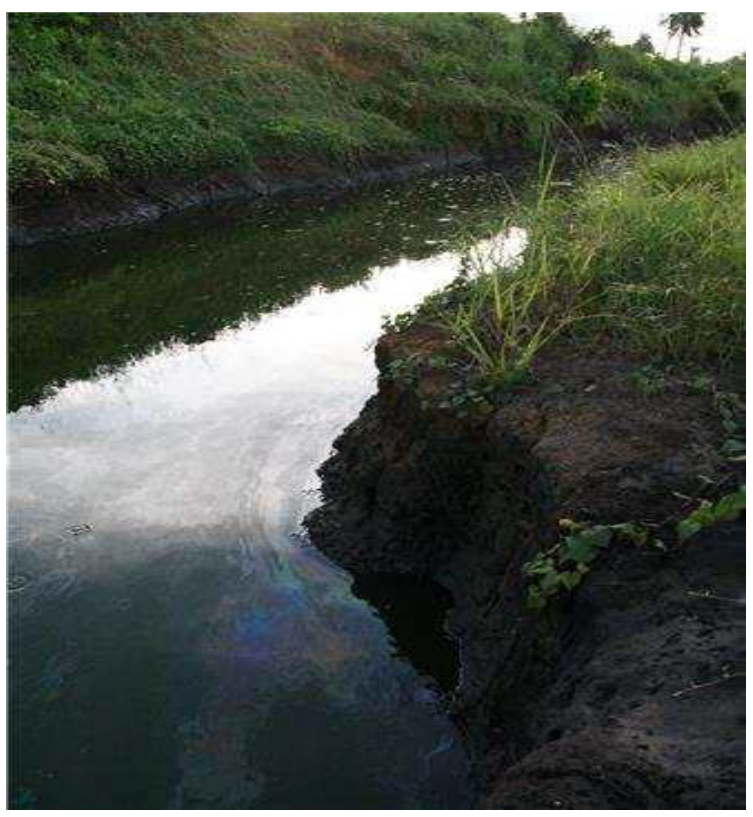

Figure 3. Oil spill in water body. Source: [19]. 
[22], Nigerian government has forcefully recovered fringe areas of lands in the According to swamps areas of Niger Delta as a result of development. Wetland degradation remains one of the challenging issue in the region as a result of population growth and the demand for space due to urbanization, agriculture, and industrialization [17]. [23] carried out a study on geospatial mapping in relation to wetland potentials in Ilesa, Osun state of Nigeria. However, it shows that agriculture and urbanization is a major threat to wetland in the area of study. According to the study, urbanization and agro-economic activities are some of the factors or activities that pressure wetland resources in the area of study. Thus, urbanisation and over cultivation of wetlands and over utilization of its resources are as a result of the population growth in the area and the suitability of the area for arable crop production. Due to these factors, the areas that were originally classified to be wetlands have been transformed to agricultural area or settlement area. The study also shows that the wetland area is been drastically reduced, while that of agriculture and settlement have increased as shown in the Table 1. This is also the case of the Niger Delta wetlands because the main occupation in the area is agriculture. The Niger Delta wetlands is assumed to be more degraded compared to wetlands in Ilesa due to the fact that people are migrating to the area in search of job as a result of the oil companies that are located within this region. Also, during the process of some companies installing their facilities, some wetland areas are being destroyed. Table 1 shows wetland areas, agricultural areas and settlement areas of two different years (1991 and 2002) calculating the difference between both years to know if the areas (wetland areas, agricultural areas and settlement areas) are increasing or decreasing in size. However, the result shows that the wetland area is decreasing while agricultural and settlement area are increasing. This affirms that agriculture and urban development is affecting wetland area.

[24] carried out a study to examine the effects of urbanization in wetlands in Lagos, and one of their findings is that the main causes of wetland loss in the study area are anthropogenic activities. The author named the activities to include high-rural urban migration, sand-filling, industrialization and dredging of wetlands. The study also identified the persistent flooding in Lagos environment during the wet season as a factor for the depletion and loss of its ecosystems. It also highlighted some consequences of economic actions on wetlands and the effects of urbanization on wetlands in the study area. Equally, direct habitat loss,

Table 1. Shows differences of land size for wetland, agriculture and settlement in 1991 and 2002 in Ilesa.

\begin{tabular}{ccc}
\hline & 1991 & 2002 \\
\hline Wetland area & $1.48 \mathrm{~km}^{2}$ & $0.89 \mathrm{~km}^{2}$ \\
Agricultural area & $90.17 \mathrm{~km}^{2}$ & $144.35 \mathrm{~km}^{2}$ \\
Settlement area & $45.41 \mathrm{~km}^{2}$ & $100.12 \mathrm{~km}^{2}$
\end{tabular}

Source: [23]. 
suspended solid additions, hydrologic variation, change in water quality, increased runoff volumes, reduced permeation, lessened stream built flows and groundwater supply resulted to prolonged dry periods which had impact on urbanization in the study area. Lagos is the most commercialised and populated city in Nigeria. For this reason, the level of wetland degradation in Lagos will be more if compared to that of Niger Delta due to high level of urban migration, industrialization and indiscriminate dumping of waste in wetlands.

Wetlands degradation is a global challenge; it is the most vulnerable ecosystems in the world, that is experiencing consistent or constant degradation and loss. According to Wetlands International, which is an NGO devoted to wetlands conservation, about $50 \%$ of the world's wetlands have been lost or disappeared in the last century [25]. In Europe, it is reported that the drainage of wetlands is known to be a collective practice. In the past century, the degree of this practice has so much increased, especially in the past 50 years to be precise. This implies that two thirds of the European wetlands that existed 100 years ago have been lost [26], this has resulted to a considerable decrease in terms of, size and quality of the natural ecosystem of wetlands. European communities are contracting parties to international treaties to help protect and conserve wetlands and its resources, like the Ramsar convention, Convention on Biological Diversity (CBD). Similarly, it involves other directives that have been decisively taken to fulfil its commitments under the convention. For example, EU Birds Directive, EU Habitats Directive, Natura 2000 network and the 1994 work programme for the implementation of the $5^{\text {th }}$ Environmental Action Programme, the Commission however, encompassed the Communication on the Wise Use and Conservation of Wetlands in it. If Nigeria can emulate this, it will not only go a long way to protect and manage the wetland and its resources, it will also introduce wetland restoration practice.

\section{Conclusion}

The Apoi creek forest wetland is very important as it harbours some endemic species. The wetland is of high economic value for the inhabitants within the locality. For this reason, there is need for the government to take over full control of the management of the wetland, due to the fact that the wetland is designated as Ramsar site of international importance; also, to establish a separate law for the management of wetlands in this region and Nigeria at large, because of its usefulness or functions. Therefore, it will be required to put in place strong sanctions for offenders of the laws. Nature is a natural asset that needs to be managed carefully. In line with this, the possible research question that will be very important to address in subsequent paper is: is the law used for wetlands management in Nigeria effective? At what rate is Apoi creek forest wetland/Niger Delta wetlands degrading?

\section{Recommendations}

This paper has highlighted the threat to Apoi creek forest (wetland) in the Ni- 
ger-Delta region. However, the factors that were outlined are anthropogenic and industrial. In finding a solution to this, the industries operating in the area or in the Niger Delta should be charged to improve their best management practice and also reduce the activities that usually result in challenging issues. Agricultural sector should improve its best management practices to reduce the activities that cause or threaten the wetland in the study area. International organizations, such as IUCN and UNEP, oil companies, the Federal Ministry of Environment, Nigeria Oil Spill Detection and Response Agency (NOSDRA) and National Environmental Standards and Regulations Enforcement Agency (NESREA) should put strict regulatory policies and sanctions on pollution and unlawful exploitation of wetland resources. This implies that anybody who goes against the law will be fined (to pay specific amount). The laws available should be properly implemented and monitored by the agencies that are mandated with the responsibility of doing so thereby reporting to the law makers for them to know if the reason for the establishment of the laws is actualized or not. If not there is need to review or modify the laws for it to achieve its aim of enactment or establishment.

\section{Author Contributions}

Both authors contributed to this study. Edo, I. carried out the design, analysis, and interpretation of the work, while E. Albrecht reviewed the work and contributed to improving the manuscript.

\section{Conflicts of Interest}

The authors declare that there are no conflicts of interest.

\section{References}

[1] Albrecht, E., Egute, T.O. and Wanki, E.A. (2016) International Environmental Law (IEL)-Agreements and Introduction. 5th Edition, BTU Eigenverlag, Cottbus-Senftenberg.

[2] Olalekan, E.I., Abimbola, L.M., Saheed, M. and Damilola, O.A. (2014) Wetland Resources of Nigeria: Case Study of the Hadejia-Nguru Wetlands. Poultry, Fisheries \& Wildlife Sciences, 2, Article No. 123.

[3] Kar, D. (2013) Wetlands and Lakes of the World. Springer, New Delhi.

[4] Desta, H., Lemma, B. and Fetene, A. (2012) Aspects of Climate Change and its Associated Impact on Wetland Ecosystems-A Review. Journal of American Science, 8, 582-596.

[5] Davidson, N.C. (2014) How Much Wetland Has the World Lost? Long-Term and Recent Trends in Global Wetland Area. Marine and Freshwater Research, 65, 934-941. https://doi.org/10.1071/MF14173

[6] Schmidt, P.R. (2006) North American Flyway Management: A Century of Experience in the United States. The Stationery Office, Edinburgh.

[7] Hoffmann, L. (1964) Proceedings of the MAR Conference Organised by IUCN, ICBP and IWRB. New Series 3, International Union for Conservation of Nature, Stes-Maries-de-la-Mer, Morges.

[8] Agbasi, N.M. and Odiaka, O.N. (2016) The Legal Framework for the Protection of 
Wetlands in Nigeria. Journal of Law, Policy and Globalization, 54, 3240-3259.

[9] Gardner, R.C. and Davidson, N.C. (2011) The Ramsar Convention. In: LePage, B.A. Ed., Wetlands, Springer, Dordrecht, 189-203.

https://doi.org/10.1007/978-94-007-0551-7_11

[10] Nwapi, C. and Ingelson, A. (2014) Environmental Impact Assessment Process for Oil, Gas and Mining Projects in Nigeria: A Critical Analysis. Law Environment and Development Journal, 10, 35.

[11] Udoh, B.T., Ibia, T.O., Udo, B.U. and Edem, S.O. (2008) Assessement of Micronutreient Status of Inland Depression and Floodplain (Wetland) Soils in Akwa Ibom state, Eastern Nigeria. Journal of Tropical Agriculture, Food, Environment and EXtension, 7, 156-161.

[12] Anwana, E. (2012) Saving the Niger Delta Red Colobus monkey from Enstinction: Enlisting the Support of Local Communities to Help Protect Apoi Creek Forest Reserve. Wild life Conservation Society, Bayelsa.

[13] Ikemeh, R.A. (2015) Assessing the Population Status of the Critically Endangered Niger Delta Red Colobus (Piliocolobus epieni). Primate Conservation, 29, 87-96. https://doi.org/10.1896/052.029.0104

[14] Protected Planet (2019) Protected Planet.net. https://www.protectedplanet.net/apoi-creek-forest-reserve

[15] Ayanlade, A. and Proske, U. (2015) Assessing Wetland Degradation and Loss of Ecosystem Services in the Niger Delta, Nigeria. Marine and Freshwater Research, 67, 828-836. https://doi.org/10.1071/MF15066

[16] Nigeria Conservation Foundation (2006). http://www.ncfnigeria.org/web/inthenews/

[17] Okonkwo, N.P. Chidumeje, K.L. and Subhashni, T. (2015) The Niger Delta Wetland Ecosystem: What Threatens It and Why Should We Protect It? African Journal of Environmental Science and Technology, 9, 451-463. https://doi.org/10.5897/AJEST2014.1841

[18] Aliyu, S.U.R. (2009) Impact of Oil Price Shock and Exchange Rate Volatility on Economic Growth in Nigeria: An Empirical Investigation. Research Journal of International Studies, No. 11, 4-15.

[19] Kadafa, A.A. (2012) Oil Exploration and Spillage in the Niger Delta of Nigeria. Civil and Environmental Research, 2, 3-12.

[20] Konne, B.R. (2014) Inadequate Monitoring and Enforcement in the Nigerian Oil Industry: The Case of Shell and Ogoniland. Cornell International Law Journal, 47, 181-204.

[21] Kuenzer, C., van Beijma, S., Gessner, U. and Dech, S. (2014) Land Surface Dynamics and Environmental Challenges of the Niger Delta, Africa: Remote Sensing-Based Analyses Spanning Three Decades (1986-2013). Applied Geography, 53, 354-368. https://doi.org/10.1016/j.apgeog.2014.07.002

[22] Abam, T.K.S. and Okogbue, C.O. (1993) Utilization of Marginal Lands for Construction in the Niger Delta. Bulletin of the International Association of Engineering Geology, 48, 5-14. https://doi.org/10.1007/BF02594972

[23] Orimoogunje, O.O.I., Oyinloye, R.O. and Soumah, M. (2009) Geospatial Mapping of Wetlands Potential in Ilesa, Southwestern Nigeria. SDI Municipality and Rescource Management, 13, 1-18.

[24] Ajibola, M.O., Adeleke, A.M. and Ogungbemi, O.A. (2016) An Assessment of Wetland Loss in Lagos Metropolis, Nigeria. Developing Country Studies, 6, 1-7. 
[25] Jansen, R. and Schuyt, K.D. (1998) Demographic Effects and Economic Values of an Ecologically Vulnerable Environment: The Case of a Tropical Wetland in Kenya. University of Maastricht, Maastricht.

[26] United Nations World Conservation Monitoring Centre (2017) Wetland Extent Trends (WET) Index. United Nations Environment World Conservation Monitoring Centre, Cambridge. 